\title{
Analysis on the Management Objectives and Measures of Modern Logistics Enterprises
}

\author{
Ying Guo \\ Qilu Normal University China Shandong 250013
}

Keywords: Modern logistics; Management goal; Strategy

\begin{abstract}
With the rapid development of China's logistics industry, the management objectives and optimization strategies of modern logistics enterprises have gradually become the focus of related professionals. This paper first introduces the basic principles of modern logistics enterprise management, and then analyzes the basic goal of modern logistics enterprise management according to the above content of logistics enterprises to improve management quality and management level of the strategy that are discussed and put forward the corresponding suggestions, and it also hopes to provide new ideas for the management of logistics enterprises carried out smoothly.

The management of modern logistics enterprises is not only the key to realize the logistics system management for enterprises, but also the basic link to promote the standardization of the market and reduce the comprehensive cost of logistics. At present, the logistics activities of enterprises have gradually risen from functional activities to the level of management strategy, and have received the attention of enterprise decision-makers. In order to further analyze the strategy of modern logistics enterprise management, we must first understand the basic principles of its management.
\end{abstract}

\section{Part One Basic Principles of Modern Logistics Enterprise Management}

\section{Principle of Goal Management}

Goal management refers to the management of basic objectives by modern logistics enterprises. The main objectives include mission tasks, overall social and economic benefits, corporate vision and so on. [1] What's more, in addition to the main target, some enterprises according to their own development but also has different goals, these goals include warehouse management, distribution management, customer service quality and so on, the premise of achieving the overall goal is not only an important indicator, but also the assessment of the various departments, and the implementation of target management also has some role.

\section{Principles of System Management}

As a system of organization, in the development process, modern logistics enterprises has gradually formed a number of interrelated and interdependent subsystems, in addition to transportation management system, distribution management system and information management and warehouse management system, its internal system includes order management system, the subsystem of coordination in the aspect of internal and external resources have their own characteristics, and gradually formed a interactively and adaptable organic system, which is not only conducive to the realization of the benefit and effect of modern logistics enterprises, and to promote rapid and healthy development of the industry that also has a certain role in promoting.

\section{Principle of System Management}

The development of enterprises is inseparable from the construction of the system. In modern logistics enterprises, management system can ensure the orderly development of logistics businesses and the normalization of business activities. [2] Divorced from the management and constraint of the system, the logistics enterprises will not only have random and chaotic management activities, but also lead to a large area of economic property loss. Thus, the management of logistics activities is of great significance to the development of modern logistics industry. 


\section{Energy Level Management Principle}

The basis of the survival of the enterprise is the profit and the principle of management that must be attached to the maximization of the interests. In the management activity, the management level can effectively improve the work efficiency of all levels, and by dividing into three levels of management to achieve high-level unified management, middle management and coordination of the active management of the grassroots management objectives, and create conditions for the realization of maximum benefit management.

\section{The Principle of Humanistic Management}

The humanistic management is the key to the management of modern logistics enterprises, and it is also the basis of management which is different from the property. Under the influence of humanistic management, the management of modern logistics enterprises should respect not only the material benefits of employees, but also the personality and self-esteem of employees, and humanized management and flexible management for employees, so as to lay the foundation for giving full play to the potential of employees.

\section{Principle of Dynamic Management}

Dynamic management is an important link of modern logistics enterprises, which is mainly because with the changing of social relations, the current logistics business behavior and employee behavior are becoming more and more complex, the management mode and use the traditional methods often do not match with the actual needs of the situation, this will reduce the effectiveness of management. [3]In order to solve this problem, we must further highlight the effect of dynamic management, achieve dynamic balance of internal management environment through dynamic management, and ultimately lay the foundation for improving management level.

\section{Part Two The Goal of Modern Logistics Enterprise Management}

\section{Provide a Perfect Service}

Modern logistics enterprises should take customer satisfaction as the highest standard of service, and serve the customers wholeheartedly, while we should also attach importance to it as the basic goal of management. In the service process, besides paying attention to the basic needs of customers, we should also attach importance to customer's quality service needs, and achieve the basic goal of logistics management by providing fast, accurate and perfect service.

\section{Reducing the Cost of Customer Management}

With the market competition environment worsening, the modern logistics enterprise customer service also gradually squeezed with many social and market factors, the logistics management services to effectively reduce the operation cost of the customers has become one of the objectives of management work. [4] Combined with the current management situation of modern logistics enterprises, in order to reduce the operating costs of customers to achieve overall benefit, we must also pay attention to resource, time, equipment, quality and information management and other aspects of the work, through the integration of resources and logistics enterprises around the whole optimization measures to further reduce the operating costs of customers, and ultimately to achieve the overall optimization of the interests of customers, create conditions for enterprises in market competition to grab the opportunity.

\section{Improving the Efficiency of Logistics Enterprises}

For the logistics enterprise itself, the higher efficiency means that the stronger market competitiveness also means more rich social and economic benefits. In the process of implementation, all management activities must focus on two basic points of service and efficiency, and provide more satisfactory services for customers based on mechanization, automation, information and intelligence. In addition, by changing the management mode and realizing the scientificity of decision-making, we can further reduce the cost and improve the efficiency of logistics management under the condition of ensuring transport capacity, thus laying a solid foundation for enterprises to get stronger market competitiveness.

\section{Meet the Basic Demand of the Market}

The development of modern logistics enterprises is not only as simple as the development of the 
industry, but also an important part of the whole process of social construction and development. Through the development of logistics, China's commodity economy can be fully constructed and perfected to realize the construction of socialist modernization in China.

\section{Part Three Optimization Strategy of Modern Logistics Enterprise Management}

Modern logistics enterprise management is a new type of enterprise management based on modern management concept and management discipline construction. It has important application value in carrying out omnibearing management process for logistics activities, and its application optimization strategy is mainly embodied in the following aspects.

\section{Make a Thorough Management Plan}

The management decision makers to make careful management plan can not only help the modern logistics enterprises to determine the basic goal of logistics management, and according to the present situation of logistics activities to forecast, [5] in order to develop business strategy and policy, but also through careful plan to coordinate the allocation of human and material activities in the process of force and financial resources, and reduce waste, reduce logistics operation risk and enhance the efficiency of logistics.

\section{Rational Organization}

With the foundation of modern logistics enterprise in considering the circulation of the entire market, business strategy, logistics management status and technical level of job content, it also needs to design the logistics organization of scientific and clear responsibilities authority problems between different institutions, and promote the logistics activities smoothly for the allocation of resources, which is also the logistics activities with the implementation of modern logistics enterprise organization plan.

\section{Improving the Effectiveness of Command Management}

Effective command and management can not only help modern logistics enterprises achieve the instructions of logistics activities, but also play a certain role in guiding subordinates to perform their duties better and achieve the tasks and objectives of modern logistics enterprises. By improving the effectiveness of command and management, it can further enhance the employees of modern logistics enterprises working attitude and enthusiasm for their work, but also can avoid the confusion caused by the command of chaos, so as to enhance the efficiency and effectiveness of logistics activities.

\section{Improving the Scientificity of Decision}

For modern logistics enterprises, scientific decision is not only the basis for modern logistics enterprises to provide logistics services for customers, but also the key to reduce logistics costs and provide design activities for customers. In the process of scientific decision making, it should not only integrate problems and materials before decision-making, but also fully predict the future development form of the industry, and work out a thorough plan to evaluate and optimize the plan. Thus it can be seen, decision-making is not a simple "clapper", but also a process of planning, evaluation and implementation. In the development process of modern logistics enterprises, only by respecting the scientific nature of decision-making and implementing scientific and modern management tools and scientific and technological means can we achieve more precise decisions, and create conditions for promoting the healthy development of the industry.

\section{Pay Attention to Control and Supervision}

Control and supervision are the process of the modern logistics enterprises to implement the logistics activities plan and to carry out feedback and challenge to the actual state according to the standard model made by the logistics enterprises. In this process, if the execution of the logistics activities is found to be deviant, the deviation can be corrected quickly and the appropriate solutions can be adjusted. Only by attaching importance to control and supervision process can we guarantee that modern logistics enterprises can avoid risks to the maximum extent when doing business, so as to effectively promote the development stability of enterprises.

In conclusion, through the management of modern logistics enterprises, we can not only improve the service level, but also reduce the operation cost of customers. It also plays an important role in 
further improving the efficiency of logistics. Based on the current situation of management of modern logistics enterprises, respectively, from the development of management plans, reasonable organization and management enhance the effectiveness of command management and enhance scientific decision-making and attach importance to supervision and control effect are elaborated, also want to be able to smoothly carry out management work to create the conditions.

\section{Reference}

[1] Yikong. Research on modern logistics enterprise management based on electronic commerce[J].Modern Trade and Industry,2016,37(34):64-65.

[2] $\mathrm{Na}$ Feng. Research on the management objectives and measures of modern logistics enterprises[J].National Business,2016,(21):19-20.

[3] Zhengnian Yin. Analysis on the management objectives and measures of modern logistics enterprises[J/OL].Modern Trade and Industry,2015,(25):1(2016-01-11).

[4] Qiyang Guo, Tingzhao. Research on cooperative mechanism of modern logistics enterprise management[J].Logistics Technology,2015,34(17):42-45.

[5] Zhenyu Li. Problems and Strategies of modern logistics enterprise management[J].Manager,2013,(25):58. 